\title{
Production/destruction in Latin America
}

\author{
Javiera Barandiarán ${ }^{1}$ \\ Casey Walsh \\ University of California, Santa Barbara, USA
}

\begin{abstract}
Rural production has long been a central topic for social sciences and history of Latin America, and scholars have noted the ways that societies and environments form around productive systems. Inspired by Gastón Gordillo's 2014 book Rubble, this article introduces a Special Section of the JPE that shifts the focus to the inseparably destructive aspects of production. We acknowledge the temporal dynamics of booms and busts in Latin American commodity production, but challenge recent tendencies to glorify destruction as necessarily and positively creative. Framing the issue as a question for Science and Technology Studies, we argue that treating technologies as rubble can shed light on dynamics of historical change, social contestation, and environmental destruction that are too often overlooked.
\end{abstract}

Key words: environment, Latin America, creative destruction, Rubble, science and technology

\section{Résumé}

La production rurale est depuis longtemps un thème central pour les sciences sociales et l'histoire de l'Amérique latine, et les chercheurs ont noté les façons dont les sociétés et les milieux se forment autour des systèmes productifs. Inspiré par le livre Rubble de Gastón Gordillo (2014), cet article présente une Section Spéciale du JPE qui met l'accent sur les aspects de production inséparablement destructeurs. Nous reconnaissons la dynamique temporelle des booms et des bustes dans la production de produits latinoaméricains, mais nous défions les tendances récentes pour glorifier la destruction comme forcément et positivement créative. Encadrer ce débat comme une question pour les études des sciences et technologies, nous soutenons que traiter les technologies comme des décombres (rubble) peut éclairer la dynamique du changement historique, la contestation sociale et la destruction de l'environnement qui sont trop souvent négligés.

Mots clés: environnement, Amérique latine, destruction créative, débris, science et technologie

\section{Resumen}

La producción económica ha sido un tema central para las ciencias sociales y la historia, sobre todo en el ámbito rural de América Latina. Muchos académicos han notado cómo las sociedades y ambientes se forman en torno a los sistemas productivos. En este artículo, inspirados por el libro Rubble (2014) [Escombros], de Gastón Gordillo, presentamos una sección especial de la Journal of Political Ecology, que incluye varios artículos de investigación que ponen atención en la esencia destructiva de la producción. En conjunto, la introducción así como los artículos de investigación que la siguen, reconocen las dinámicas temporales de los auges y crisis que la producción de mercancías, alimentos, minerales y otros han desencadenado en America Latina, al tiempo que cuestionan la tendencia - común entre economistas y otros que promueven políticas productivas - de glorificar la destrucción como algo necesario y positivo, parte de una gran 'producción creativa' que mueve a la economía nacional. Asimismo, avanzamos la idea que estudiar las tecnologías como

\footnotetext{
${ }^{1}$ Dr. Javiera Barandiaran, Assistant Professor, Department of Global Studies, University of California, Santa Barbara, 93106, USA. Email: jba "at" global.ucsb.edu. Dr. Casey Walsh, Director, Latin American and Iberian Studies and Associate Professor, Department of Anthropology, University of California, Santa Barbara, Santa Barbara, CA. 931063210, USA. Email: walsh "at" anth.ucsb.edu. The articles in this Special Section of the JPE were developed in a workshop, Production/destruction: Latin America environments, held at UCSB on April 8-9, 2016. The authors wish to thank all the participants, as well as those who supported the workshop at UCSB: the Latin American and Iberian Studies Program, the Department of Anthropology, the Interdisciplinary Humanities Center, and the Division of Social Sciences. This is the introductory article in Javiera Barandiarán and Casey Walsh (eds.). 2017. "Production/destruction in Latin America", Special Section of the Journal of Political Ecology 24: 716-800.
} 
escombros (rubble en el sentido analítico de Gordillo) y desde perspectiva de los llamados Estudios Sociales de la Ciencia y Tecnología, ayuda a clarificar diferentes dinámicas asociadas al cambio histórico, protesta social, y destrucción ambiental, dinámicas a menudo ignoradas por académicos cuando no usan este enfoque analítico.

Palabras clave: medioambiente, América Latina, destrucción creativa, ruinas, ciencia y tecnología.

\section{Introduction}

In 1968, ecologist Paul Ehrlich published his doomsday bestseller, The population bomb, warning that the Earth could not sustain a booming population. On popular TV shows Ehrlich explained at the time that human demands were outstripping the Earth's natural resources and their capacity to provide sufficient food, clothing and shelter for a growing human population. Fear gripped many young American environmentalists fear of out-of-control population growth, of widespread scarcity and of global environmental collapse. But economists, led by Julian Simon, had an answer to Ehrlich's concerns: human ingenuity in the form of technologies and adjusting markets would find new forms of production and alternative resources with which to meet demands, without destroying the environment. The rivalry between these two men and their opposing views played out through a televised bet: Simon bet Ehrlich than in one decade the prices of five metals -to be chosen by Ehrlich- would fall thanks to substitutions and efficiency gains triggered by market adjustments and technological advancements (Sabin 2013). By 1990, at the decade's end, the prices of these metals had fallen, and Simon could say that there was no need to fear the population bomb. The rules of the market, where supply and demand adjust to each other, had created aggregate stability and averted a global crisis.

But Simon's victory was fragile. If Ehrlich had chosen a longer time period or a bigger basket of global commodities, he might have won. Between 1960 and 2007 the prices of several key metals and of hydrocarbons produced in Latin America have increased (Bury and Bebbington 2013), and World Bank data on food prices show that 2012 world food prices are on a par with their level in 1960 . World food prices fell from their peak soon after the oil shocks of the 1970s to an all-time low during the 1980s and 1990s, but have risen since $2005 .^{2}$ Moreover, the bet did not settle the core dispute between Ehrlich and Simon: can capitalist production and technological innovation provide real solutions to humanitys' multiple needs for sustainable and healthy livelihoods? Perhaps more important, can capitalism avert looming global-scale forms of environmental destruction such as the mass extinction of species and climate change?

In this Special Section of the Journal of Political Ecology we grapple with these questions by conceptualizing production as always inseparable from destruction. Inspired by Gastón Gordillo's book Rubble, we maintain this dialectical focus on production/destruction by studying the forms of rubble left by contemporary capitalism in rural spaces in Latin America (Gordillo 2014). The authors thus do not reproduce the polarized debates about climate change that followed Ehrlich and Simon's bet, in which optimists championed a free-market, techno-utopia against dystopian visions of global collapse (Sabin 2013). Nor do they reproduce simplified narratives of inevitable environmental decline in Latin America.

Instead, the articles in this Special Section consider the political ecology of economic development in ways that recognize the importance of time and rhythms in growth and that go beyond the familiar framing in terms of inequality. This perspective recovers elements of a tradition of anthropological political economy that has informed political ecology from its inception (Greenberg and Park 1994; Mintz 1984; Wolf 1972; Wolf 1984). At the same time, however, the authors engage with science and technology studies to push political ecology toward crucial human-environment issues such as extractivism, biotechnology, the limits of industrial agriculture, and shifting balances in the dialectic of production/destruction.

In this introduction, the Special Section editors define and discuss production/destruction and two of its analytical contributions: technologies and resistance. The articles focus on food production in Latin America, both on land and at sea, and take a historical and anthropological view. The articles reflect upon the social and environmental question of who in particular areas of Chile, Brazil or Ecuador has benefitted, and who has suffered, from certain booms: in nitrogen use, in beef production, in for-export agriculture, and in

\footnotetext{
${ }^{2}$ Wenzlau, Sophie, 'Global food prices continue to rise', posted April 11, 2013, World Watch Institute website (http://www.worldwatch.org/global-food-prices-continue-rise-0, accessed September 15, 2016).
} 
marine aquaculture. Together, the articles cover the rise of the Green Revolution, its consolidation in export agriculture, and the expansion of its principles into a new frontier, the ocean.

\section{Production/Destruction}

In her recent book, Expulsions (2014), Saskia Sassen reminds us that economic growth has never been benign. That capitalism has a "downside" is a central assumption in Marxist analyses that focus on, for example, the manner in which accumulation is achieved through dispossession and exploitation of labor, or the cyclical patterns of growth and crisis (Harvey 1982). In mainstream economics, these contradictions are eloquently captured in the idea of "creative destruction", coined by Joseph Schumpeter in 1942 to describe the mechanism for growth in capitalism. In a dynamic economy, he argued, entrepreneurs selling new technologies and consumer goods displace (and thereby destroy) incumbent firms. Economists have since debated what needs to be destroyed by the new competition - is it the individual entrepreneur, the firm or the industry as a whole? Schumpeter himself was cautious about creative destruction, and advocated for corrective measures to increase economic stability (Perelman 1995). Today, however, economists have generally embraced the inherent instability creative destruction implies. Not only are the corrective measures Schumpeter advocated for -protecting monopolies- today politically unthinkable, but many economists dedicate their research to finding obstacles to creative destruction that must be removed. For example, Chilean MIT economist Ricardo Caballero finds that job security provisions hamper creative destruction (Caballero 2008), and innovation economists argue that protecting industries or firms from creative destruction amounts to protecting obsolete technologies and incumbent power (Malerba and Brusoni 2007).

This reframing of the concept of creative destruction is part of a neoliberal critique of mid-twentieth century development economics, and the central role of the state in the double effort to promote growth and fend off stagnation (Harvey 2006). Development from this point of view was often cast as a problem of jumpstarting "backward" economies by providing factors of production such as technology, government regulation, skilled labor or capital (Gershenkron 1962; Hirschman 1958). Non-market actors were privileged actors for carrying out these sorts of policies, and during the twentieth century Latin America became something of a laboratory for efforts to make growth happen through strategies such as Import Substitution Industrialization and later the sowing of petrodollars (Coronil 1997; Urquidi 2005). When these development perspectives fell from grace during Latin America's "lost decade" of the 1980s, the awareness that capitalism is a process that destroys as it produces also faded. Projects promoted by a new generation of "trustees" of development promised only progress from the policies of liberalization they promoted (Cowen and Shenton 1997). Human and environmental welfare was left to a market dynamic that was increasingly portrayed as predictably positive, despite evidence to the contrary. "Creative destruction" was embraced anew, not as an analytical tool for understanding the positive/negative dialectics of development, but rather as one to render the destruction wrought by unfettered capital acceptable, even desirable.

Economists' embrace of creative destruction and disregard for the suffering it generates is an example of what Ann Stoler has called "imperial disregard" (Stoler 2008). The economists are not ignoring the consequences of job insecurity, rather they "refuse to take notice of it" (Stoler quoted in Gordillo 2014: 80). As Gordillo points out, "this inattention is central to the elite disregard for destruction", the flipside of their enthusiasm for spectacular places and the ruins of past spectacular places. Drawing on Lefebvre and Debord, Gordillo identifies such spectacular places as $19^{\text {th }}$ century Paris or the skylines of today's global financial centers. To this list we might add today's places of technological advance, such as Google's or Apple's "campuses" near Palo Alto, California, which sit where orchards flourished until just a few decades ago, or the laboratories of biotechnology powerhouses. These built environments include everything from the campuses of the University of California system (discussed in San Martín 2017) to corporate giants like Monsanto (now Bayer) or Marine Harvest (see Gerhart 2017). We can also add the immense fields of monocrop soy spreading out in Southern Brazil and northern Argentina, their straight lines a defiance of nature.

It is against the spectacle and ideology of these places that Gordillo asks us to deploy instead the concept of "destructive production", which not only eliminates any romanticism the term creative destruction might suggest, but also calls our attention to the rubble that capitalism leaves behind. Gordillo's concept of history has a Frankfurt school voicing: Walter Benjamin's Angel of History also gazes back as the "storm" of 
capitalism "unceasingly piles rubble on top of rubble and hurls it before his feet" (Benjamin 1969 [1940]). Of the same era, Schumpeter shared Benjamin's feeling for what he called the "perennial gale of creative destruction" (Schumpeter 2008 [1942]), as well as his imperative of using history to discern its true visage. To look for and at rubble is thus "a disposition to disregard those places fetishized by elites and to face, instead, the voiding of space exuded by rubble" (Gordillo 2014: 81). Gordillo follows Benjamin's musings on how urban built environments and industrial commodities can support an awareness of the temporality of regimes of capitalist accumulation (Buck-Morss 1991), but shifts the gaze to the "upstream" rural spaces of commodity production that are characteristic of Latin America. Inspired by this approach, the authors of the following articles look for rubble as a way to make visible the destruction and dislocation caused by new forms of agricultural, pastoral and aquacultural production.

\section{Rhythms in economic growth}

On a given day, the business section of any major newspaper will report with glee about some enticing booms: in construction, in housing prices, in demand for Apple products, or in China's demand for minerals, metals, and agricultural commodities. Although investors celebrate these booms, to many others a boom foreshadows a future bust. Boom/bust cycles have wheeled through Latin American economy and society since at least the $16^{\text {th }}$ century, only partially enabled or controlled by state regulation (Topik, Marichal and Frank 2006; Walsh 2008). In the new global order, the 2008 recession began as a housing boom that went bust, and since 2014 China's demand for minerals has slowed enough to raise the specter of a region-wide bust in Latin America. The specter of a bust lurks at the heart of the resource curse, the theory that economies that rely heavily on extractive industries (typically minerals or fossil fuels) are prone to economic instability and poverty more so than diversified economies. Like creative destruction, boom-bust events and resource curse theories call attention to the cyclical nature of economic growth, in contrast to neoclassical economic growth theories that assume markets can reach stable equilibrium and that wealth can continue to expand (therefore, as promoted particularly by the followers of Friedman, rendering redistribution unnecessary). This latter range of ideas has also inspired enduring political-cultural ideologies such as modernization theory, in which countries develop according to a linear, step-wise plan, and negative dimensions such as poverty and periodic busts are largely ignored or relegated to some "external" conceptual domain (Rostow 1991 [1960]).

A series of recent economic transformations, laid bare by the 2008 global recession, remind us however that production/destruction cycles are the norm, and stable growth an illusion. In Latin America, this kind of economic activity is reaching further into previously out-of-reach lands. Some of these have been made accessible by climate change, such as high-mountain mineral deposits (Bury 2015). Other deposits we can now reach with new technologies, such as horizontal drilling used to extract shale gas and oil deposits And a combination of agricultural technologies and economic incentives are pushing investors to convert old forests and small farms into fields for industrial soy agriculture. Saskia Sassen (2014) ties these trends together through the concept of expulsions, a kind of "savage sorting" happening today with unprecedented speed as capitalism appropriates Latin America's natural resources while expelling biological life and classes of humans from production. The comfortable consumer middle class that was once critical to the development of capitalism is less important for accumulation, as profits are realized not through greater sales but by squeezing the costs of production. Land grabs, Sassen emphasizes, are central to the expulsions we are currently witnessing, and are analyzed in several of the articles in this Special Section.

"The destruction of space needs to be understood also in terms of its rhythms, temporalities, and intensities", writes Gordillo (2014: 82). It is a process that is unstable and contradictory, as the contributions to this Section depict. One of the contradictions lies in the juxtaposition of relatively long cycles with acute moments of expulsion and destruction; the "organic" and "conjunctural" movements described by Antonio Gramsci in his analysis of economy and political culture (1971). In the contributions to this Special Section, the spaces being destroyed in Latin America are not suffering from war or even from disastrous events. Instead they are being destroyed to promote the production of new consumer goods or raw materials for industrial processes. Certain spaces and natures are destroyed to enable someone's business opportunity; read systemically, this is David Harvey's "spatial fix" to the crisis of accumulation provoked by falling rates of profit (Harvey 1982). People experience the pace and intensity of these changes in ways that can be difficult 
to anticipate and which matter for how economic growth occurs in a specific place. Some communities, like fishermen in southern Chile or ranchers in Brazil's Amazon, have accommodated themselves to changes in the landscape induced by new capital investments more so than others, such as indigenous communities in highland Ecuador. But these accommodations have their limits; as Gerhart (2017) shows, Chilean fishermen withdrew their support of the farmed salmon industry once they felt expelled from the benefits this mode of capitalist production had promised.

One response to these experiences with business cycles is nostalgia, and another is speculation. For example, nostalgia is a common emotion among men who worked in unionized manufacturing jobs (Bear 2015; Grandin 2009), among farmers who benefitted from the cotton boom in northern Mexico (Walsh 2008) and among former artisanal fishermen in southern Chile (Gerhart 2017). Meanwhile, in the business press, speculation has become an acceptable way to talk about the future; economic booms imply, perhaps require, speculation, as evidenced by coverage of current "booms" in shale oil and gas or lithium production. The changing balance of production/destruction is experienced and understood through these narratives of nostalgia and speculation. The point here is to contrast these unruly categories of time against measured categories such calculation, prediction or insurance, as well as against declensionist environmental narratives in which environmental degradation is constant and inevitable. Whether or not capitalist production is accelerating, as Sassen (2014) claims, or just operating through new technologies and global relationships that are producing new forms of environmental destruction, recent work on the rhythms of economic growth including this Section- calls on scholars to refine their concepts and analytical focus on time (e.g., Bear 2015). Given climate change, this call is all the more urgent for scholars of the environment.

\section{Contributions of Production/Destruction}

\section{Technologies as Rubble}

Aware that many citizens think of busts with fear, policy-makers and political leaders intent on attracting resource-intensive development to their jurisdictions often promise to take steps to preempt the feared bust by investing in education or infrastructure. The hope these leaders profess is that such investments will bear fruit in the form of new, higher-value industries, before resource extraction goes bust. This ideal, grounded in innovation theories that trace their intellectual lineage back to Joseph Schumpeter, has recently been revitalized in policy circles in many Latin American countries. For example, Chile recently created a Council of Innovation for Economic Competitiveness which recommended focusing research spending on five strategic clusters (CNIC 2007), and some policymakers support transferring the country's science funding agency from the Ministry of Education to the Economy. ${ }^{3}$ Mexico's recent turn to nanotechnology is motivated by the same goals (Delgado 2008). The World Bank has promoted similar policies through its "knowledge for development" program, and lithium industrialization policies in Bolivia include a significant innovation component (Revette 2017). All these policies share a faith in the ability of scientific and technological innovation to break cycles of production/destruction, and counteract the social discontent associated with the negative of development. They assume that science is beyond politics.

Scholars of technology, however, have long argued that technologies have politics and are best understood as embedded in social and political systems (Hughes 1983; Winner 1980). Research into technopolitics, "a concept that captures the hybrid forms of power embedded in technological artifacts, systems and practices" (Hecht 2011: 3), examines how political goals are enacted through technology, including in design decisions. What makes technology particularly interesting for scholars of politics and society is that it renders asymmetries of power less visible, by rationalizing them into design, product development, or production decisions (Hecht 2011). For example, production technologies have a long history of producing and obscuring the uneven distribution of toxic pollution from energy, mining or industrial facilities (for a review, see Ottinger et al. 2016). Bear (2015) likewise points to the role of "austerity

\footnotetext{
${ }^{3}$ This is an ongoing debate in Chile. See the report by the President's Committee on Science for Development, delivered to President Bachelet in July 2015 (Un sueño compartido para el futuro de Chile); Michele Catanzaro's article "Chile puts plan for science ministry on hold" (March 27, 2014); and an open letter from Chilean academics opposing a 2012 proposal to move the agency into the Ministry of Economics, available from JB by request.
} 
technologies" in implementing and naturalizing austerity capitalism, with all its unequal and unjust effects. And in this Section, examples include water distribution systems that favor large farmers over indigenous peasants that are rationalized as technologically superior (Partridge 2017), as well as the science and technology-intensive Green Revolution (San Martín 2017).

At a global scale, technopolitics have also helped sustain uneven effects and colonial hierarchies. European colonizers often judged non-Western cultures as technologically inferior and therefore in need of intervention (Adas 1989). They used their technological prowess to dominate other societies politically and economically, and to delegitimize traditional or local knowledge. In response, after the end of World War II, many leaders of the newly coined "Third World" saw in science and technology a sure way to achieve modernity (Moon 2007; Prakash 1999). Whether the goal was to "catch-up" to the West or challenge Western hegemony through alternative, "appropriate" technologies, to many Third World governments, technology policies were about economic growth and development (Fressoli et. al. 2014; Medina et al. 2014). This spirit was evident in how the Chilean government embraced the Green Revolution (San Martín 2017), and it contributes to Brazilian cowboys' enthusiasm for cattle ranching, as they celebrate technologies like front-end loaders as symbols of power and progress (Hoelle 2017).

Combining analyses of sociotechnical systems with Gordillo's materialism, these articles treat technologies as actual or potential rubble. In seeing disused technologies as rubble, the articles by Partridge and San Martin emphasize the ways in which political and social progress can render technologies obsolete in other words, technologies do not succumb only to technological advance. This insight provides yet another challenge to technological determinism, revitalized by talk of globalization as the inexorable result of technological advance. Instead, in treating technology as rubble, these articles show the complex local politics of global technoscientific projects, in ways that bring postcolonial concerns to the study of globalization. In an essay on the need for postcolonial STS analysis of globalization, Warwick Anderson (2009) recounts the success of STS scholarship in challenging linear and homogenous accounts of progress, calling out the triumphalism and exceptionalism typically found in Western accounts of progress. This scholarship has advanced through studies of how technical knowledge and practices travel across cultural and geopolitical divides, and how they fare on arrival. Sometimes technologies travel as 'immutable mobiles' that collapse differences between center and periphery (Latour 1987). Other times technologies become ubiquitous because they are mutable; they retain their distinctiveness and interpretative flexibility across different contexts and users (de Laet and Mol 2000; Hecht 2011; Medina et al. 2014). But in all these conceptions technologies are yet to be treated as rubble.

When seen as rubble, disused technologies stand out not for their mobility but for their permanence. Thus, as rubble, obsolete technologies can continue to have political power, long after their sophistication has waned, as Partridge argues in his analysis of indigenous activism against the use of cannons in highland Ecuador (2017). Partridge examines ongoing environmental conflicts in highland Ecuador triggered by this unlikely agricultural technology: anti-hailstone cannons deployed by plantations that produce broccoli for export. Even after the plantation owners were forced to remove the cannons in response to social protests, they continued to exert political influence as surrounding communities seized on them to keep grievances related to unequal and inadequate access to water simmering in the public debate. Though seemingly a simple accessory to the causes of poverty and marginalization among highland indigenous communities, when seen as rubble, the cannons instead expose the ways in which colonial and modern legacies of disempowerment are reinvented in the present, and provide opportunities for new alliances and relationships of resistance to be formed. Importantly for postcolonial concerns, Partridge connects these legacies to a suite of "resource sovereignties", including food sovereignty and sovereignty over the skies.

Finally, though recognizing the ruins of cutting-edge technologies as rubble requires retraining one's gaze, the effort can ultimately help scholars and communities overcome an ideological characteristic of technologies - that they make inequalities less visible. In the case of salmon farms in southern Chile, Gerhart (2017) shows how recognizing abandoned farms as rubble helps communities and scholars recognize forms of destruction that are otherwise out-of-sight. Gerhart tells the history of salmon aquaculture in Chile, from the origins of the first commercial hatcheries in the 1970s, through the boom years of the 1990s and early 2000s, to the industry's collapse in 2007-2010 when an influenza-like virus, called ISA, killed millions of fish. 
According to Gerhart, before and after the ISA virus crisis, this was a "legally designed" monoculture, bound to fail as spectacularly as it did (and then bounce back). Part of the difficulty in this case is that ocean waters obscure our view of the ecological debris that results from intensive aquaculture. From land, a salmon farm with good husbandry practices and one without, one with over-packed cages and one that is abandoned, can be hard to distinguish. In this case, seeing technologies as actual or potential rubble helps viewers connect multiple levels of ecological destruction.

\section{Modes of resistance}

Some of the economic rhythms of negative and positive might include the possibility of transformation. The key here is to move beyond our conceptual divide between resources and "waste" and highlight how rubble itself is a resource for production of social spaces and movements. Rubble invites those possibilities for renewal and regeneration in particularly strong ways (Bear 2015; Gordillo 2014). Gordillo forcefully argues that, in refusing to fetishize ruins, those who have been expelled or made obsolete by "progress" are resisting triumphalist narratives of development. Like Hindu communities in West Bengal (Bear 2015), the rural communities of Argentina that Gordillo studied expressed their resistance through celebrations held at the ruins of development. Similar to visiting the cemetery on the Day of the Dead, community-wide rituals held at nodes of rubble allow for a celebration of collective memories of violence and a reclamation of histories that stretch beyond the boom and bust cycles of capital and remain powerful in the present day. With these acts, communities can question the inevitability of destruction that is embedded in pessimistic and declensionist narratives of environmental degradation.

Celebrations, rituals and protests organized around sites of rubble can perhaps help arrest the pace of and ameliorate the human suffering caused by production/destruction. First, recognizing and celebrating nodes of rubble reminds us that a lot of what we know about the history of nature and society is through the study of and experiences with destruction. To an optimist, this suggests that as scholars or communities become increasingly expert in destruction, our ability to detain or reverse such trends might improve. San Martín and Gerhart both provide some hints of this process. In his study of nitrogen use and the Green Revolution, San Martín uses the dialectic of production/destruction to break with for-or-against narratives that fail to capture the range of impacts on food production and the environment of the Green Revolution. In particular, San Martín (2017) highlights how the institutions and networks created to spread the Green Revolution also enabled the production of counter-narratives. Thus, the same networks that promoted nitrogen use became, over time, crucial to understanding the host of negative environmental impacts this fertilizer has come to have. While San Martín sees in these networks the potential for change, Gerhart's analysis is less optimistic, and points instead to some worrisome trends in the farmed salmon industry (2017). The silver lining, however, lies in his somewhat "posthumanist" discussion of agency - in highlighting the agency of viruses and fish, who repeatedly defy human efforts to control them, Gerhart demonstrates the limits to, and power of, human agency. An agency which, in contrast to that of fish or viruses, should be held fully responsible for its actions.

Second, recognizing that environmental destruction is not inevitable helps to remind us of the fact that production is contingent, for example, on consumer and citizen demands for less destructive products and more protective regulation. The production/destruction detailed in the articles that follow results from global food markets that are regulated across levels of government - local, state, regional and international. Most (though not all) of the consumers are located far away from the sites of production/destruction, in China (soy) or the U.S. and European countries (salmon, broccoli). However, Partridge argues, imposing restrictions on productive/destructive activities is not always enough for redressing ongoing inequalities rooted in resources.

\section{Surviving the booms}

Writing about another form of spatial production/destruction, the rapid gentrification of some neighborhoods in San Francisco, California, novelist Daniel Alarcón suggests that to know a person's social standing, we might well ask: "What shading do they give to the word boom? Do they use it to evoke a colorful futurist dream, or do they use it to imply destruction? Do they say it with a hint of awe, or as though they simply hope to survive it?" (Alarcón 2014). Production/destruction draws our attention to how social groups, 
including entire classes, try to survive the intersecting forces of global capitalism, technological change, and environmental destruction. Which life forms are best suited to survive this pace of change, and which are not? Which, if any, might thrive in a world of intensive production/destruction? Gerhart (2017) makes a compelling case that sea lice, influenza viruses, algae blooms, and noxious bacteria that defy technocratic forms of control are best suited to survive, even thrive, in this world, unlike the fishing communities who initially benefited from jobs in salmon farming until they were replaced by machines. By contrast, Hoelle (2017) suggests that under some conditions some human groups might also thrive, at least for a while - for instance, in Acre, Brazil, many local residents embrace the Amazonian rubble created by ranching because the resulting meat is highly valued and widely accessible to them. For them the transformation of the Amazon by agrarian capital is understood in positive, productivist terms rather than as destruction or rubble.

Which communities survive production/destruction, and what specific practices and narratives they use to make sense of their survival, are pressing questions for scholars of politics and society in a world of rising inequality. In the past two decades, the wealth of the top one percent globally increased 60 percent. And between 2002 and 2011 - a period that included the greatest recession seen in our lifetimes - bank assets grew by 160 percent (Sassen 2014). Global capitalism today makes profits by squeezing production and concentrating consumption among the rich, or squeezing pennies from the destitute, rather than by paying working classes enough to afford the outputs of their manufacturing labor, nor by fostering an affluent middle class (Elyachar 2002). In Brazil's Amazon, for instance, industrialists no longer attempt to create orderly worksites that offer education and health services, as Henry Ford once did, but instead promote free-trade zones that attract desperate workers who earn poverty wages at assembly plants. These workers suffer crime, abuse, pollution and poor health care, steps away from luxury high-rises along the Amazon River (Grandin 2009). Along another river in India, workers cope with austerity capitalism through ethical fixes that range from new navigation tools to revitalized cultural narratives about reciprocity and solidarity (Bear 2015). In Rubble, Gordillo similarly examines the rituals and practices of gaucho communities displaced by highly capitalized soy farms, and finds that these are informed by the gauchos' experiences as the beneficiaries of a previous cycle of accumulation, when they displaced colonial society and indigenous tribes, while promising to bring modernity and prosperity.

These anthropological and historical works have in common a focus on understanding how communities survive, politically and culturally, the transformations caused by global capitalism. They highlight that while communities may be facing similar global forces, they respond in ways specific to their time and place. In 2016, in the wake of the vote in the United Kingdom to exit the European Union and in the United States to elect a fear-mongering candidate for president, studies that focus on how specific sectors of society cope with, rationalize, and narrate their fears of loss and nostalgia for previous cycles of accumulation seem necessary for understanding electoral results that technocratic tools like opinion polls and surveys misjudged. We believe the contributions to this Special Section suggest that the dialectic of production/destruction, paired with Gordillo's notion of rubble, are particularly useful concepts for these kinds of studies, as they change the terms of polarized environmental and economic debates.

\section{Production/destruction in Latin American environments, edited by Javiera Barandiarán and Casey Walsh}

1. Andrew Gerhart. Petri dishes of an archipelago: the ecological rubble of the Chilean salmon farming industry.

2. Jeffrey Hoelle. Jungle beef: consumption, production and destruction and the development process in the Brazilian Amazon.

3. Tristan Partridge. Resisting ruination: resource sovereignties and socioecological struggles in Cotopaxi, Ecuador.

4. William San Martín. Nitrogen, science, and environmental change: the politics of the green revolution in Chile and the global nitrogen challenge.

5. Gastón Gordillo. On the destructive production of food: some lessons from South America. 


\section{References}

Adas, M. 1989. Machines as the measure of men: science, technology and ideologies of western dominance. Ithaca: Cornell University Press.

Alarcon, D. 2014. The mission: creative destruction in eleven parts. New York Magazine March 9. http://nymag.com/news/features/san-francisco-mission-district-zuckerberg-2013-4. $\quad$ (accessed September 11, 2016)

Anderson, W. 2009. From subjugated knowledge to conjugated subjects: science and globalisation, or postcolonial studies of science? Postcolonial Studies 12(4): 389-400.

Bear, L. 2015. Navigating austerity: currents of debt along a south Asian river. Palo Alto, CA: Stanford University Press.

Benjamin, W. 1969 [1940]. Theses on the philosophy of history. In H. Arendt (ed.) Illuminations: essays and reflections. New York: Penguin/Random House.

Buck-Morss, S. 1991. The dialectics of seeing: Walter Benjamin and the arcades project. Cambridge: MIT Press.

Bury, J. 2015. The frozen frontier: the extractives super cycle in a time of glacier recession. In C. Huggel, J. Clague, A. Kaab, and M. Carey (eds.) The high-mountain cryosphere: environmental changes and human risks. Cambridge: Cambridge University Press.

Bury, J. and A.J. Bebbington. 2013. New geographies of extractive industries in Latin America. In A.J. Bebbington and J. Bury (eds.) Subterranean struggles: new dynamics of mining, oil, and gas in Latin America. Austin: University of Texas Press.

Caballero, R. 2008. Creative destruction. In S. Durlauf and L. Blume (eds.) The new Palgrave dictionary of economics. Second edition. Palgrave Macmillan.

CNIC. 2007. Hacia una estrategia nacional de innovación para la competitividad. Vol. 1. Santiago, Chile: Consejo Nacional de Innovación para la Competitividad.

Coronil, F. 1997. The magical state: nature, money and modernity in Venezuela. Chicago: University of Chicago Press.

Cowen, M. and R. Shenton. 1997. Doctrines of development. London: Routledge.

DeLaet, M. and A. Mol. 2000. The Zimbabwe bush pump: mechanics of a fluid technology. Social Studies of Science 30(2) 225-63.

Delgado, G. 2008. Guerra por lo invisible: negocio, implicaciones y riesgos de la nanotecnología. Mexico: UNAM.

Elyachar, J. 2002. Empowerment money: the World Bank, non-governmental organizations, and the value of culture in Egypt. Public Culture 14(3): 493-513.

Ferguson, J. 1990. The anti-politics machine: "development", depoliticization, and bureaucratic power in Lesotho. New York: Cambridge.

Fressoli, M., and E. Arond. 2015. Technology for autonomy and resistance: the appropriate technology movement in South America. Working Paper 87. Brighton: IDS, STEPS Centre.

Gerhart, A. 2017. Petri dishes of an archipelago: the ecological rubble of the Chilean salmon farming industry. Journal of Political Ecology 24: 726-742.

Gerschenkron, A. 1962. Economic backwardness in historical perspective, a book of essays. Cambridge: Belknap Press of Harvard University Press.

Gordillo, G. 2014. Rubble: the afterlife of destruction. Durham N.C.: Duke University Press. Academia, intro

Gordillo, G. 2017. On the destructive production of food: some lessons from South America. Journal of Political Ecology 24: 797-800.

Gramsci, A. 1971. Selections from the prison notebooks. New York: International Publishers.

Grandin, G. 2009. Fordlandia: the rise and fall of Henry Ford's forgotten jungle city. New York: Picador.

Greenberg, J. and T. Park. 1994. Political ecology. Journal of Political Ecology 1(1): 1-12.

Harvey, D. 1982. The limits to capital. New York: Verso. 
Harvey, D. 2006. Neoliberalism as creative destruction. Geografiska Annaler. Series B, Human Geography 88(2): 145-158.

Hecht, G. (ed.). 2011. Entangled geographies: empire and technopolitics in the global cold war. Cambridge: MIT Press.

Hirschman, A. 1958. The strategy of economic development. New Haven: Yale University Press.

Hoelle J. 2017. Jungle beef: consumption, production and destruction and the development process in the Brazilian Amazon. Journal of Political Ecology 24: 743-762.

Hughes, T. 1983. Networks of power: electrification in western society, 1880-1930. Baltimore, MD: John Hopkins University Press.

Latour, B. 1987. Science in action: how to follow scientists and engineers through society. Cambridge: Harvard University Press. intro

Malerba, F. and S. Brusoni. 2007. Perspectives on innovation. Cambridge: Cambridge University Press.

Medina, E., I. da Costa Marques and C. Holmes (eds.). 2014. Beyond imported magic: essays on science, technology and society in Latin America. Cambridge: MIT Press.

Mintz, S. 1984. Sweetness and power: the place of sugar in modern history. New York: Penguin.

Moon, S. 2007. Technology and ethical idealism. Leiden: CNWS Publications.

Ottinger, G., J. Barandiaran and A.H. Kimura. 2016. Environmental justice: knowledge, technology and expertise. In Felt, U., R. Fouché, C. Miller and L. Smith-Doerr (eds.) The handbook for science and technology studies. 4th edition. Cambridge: MIT Press.

Partridge, T. 2017. Resisting ruination: resource sovereignties and socioecological struggles in Cotopaxi, Ecuador. Journal of Political Ecology 24: 763-776.

Perelman, M. 1995. Retrospectives: Schumpeter, David Wells, and creative destruction. The Journal of Economic Perspectives 9: 189-197.

Prakash, G. 1999. Another reason: science and the imagination in modern India. Princeton: Princeton University Press.

Revette, A.C. 2017. This time it's different: lithium extraction, cultural politics and development in Bolivia. Third World Quarterly 38(1): 149-168.

Rostow, W. 1991 [1960]. The stages of economic growth: a non-communist manifesto. Third Edition. Cambridge: Cambridge University Press.

Sabin, P. 2013. The bet: Paul Ehrlich, Julian Simon, and our gamble over the Earth's future. New Haven: Yale University Press.

San Martín, W. 2017. Nitrogen, science, and environmental change: the politics of the green revolution in Chile and the global nitrogen challenge. Journal of Political Ecology 24: 777-796.

Sassen, S. 2014. Expulsions: brutality and complexity in the global economy. Cambridge, MA: Belknap Press.

Schumpeter, J. 2008 [1942]. Capitalism, socialism and democracy. Third edition. New York: Harper Perennial.

Stoler, A. L. 2008. Imperial debris: reflections on ruins and ruination. Cultural Anthropology 23(2): $191-219$.

Topik, S., C. Marichal and Z. Frank. 2006. From silver to cocaine: Latin American commodity chains and World history. Durham N.C.: Duke University Press.

Urquidi, V. 2005. Otro siglo perdido: las políticas de desarrollo en América Latina (1930-2005). México: Fondo de Cultura Económica/Colegio de México.

Walsh, C. 2008. Building the borderlands: a transnational history of irrigated cotton along the Mexico-Texas border. College Station: Texas A\&M Press.

Winner, L. 1980. Do artifacts have politics? Daedalus 109: 121-136.

Wolf, E. 1972. Ownership and political ecology. Anthropological Quarterly 45(3): 201-205.

Wolf, E. 1984. Europe and the people without history. Berkeley: University of California Press. 